University of Nebraska - Lincoln

DigitalCommons@University of Nebraska - Lincoln

$10-2004$

\title{
Observations on Myiasis by the Calliphorids, Bufolucilia silvarum and Bufolucilia elongata, in Wood Frogs, Rana sylvatica, From Southeastern Wisconsin
}

\author{
Matthew G. Bolek \\ Oklahoma State University, bolek@okstate.edu \\ John J. Janovy Jr. \\ University of Nebraska - Lincoln, jjanovy1@unl.edu
}

Follow this and additional works at: https://digitalcommons.unl.edu/bioscijanovy

Part of the Parasitology Commons

\begin{abstract}
Bolek, Matthew G. and Janovy, John J. Jr., "Observations on Myiasis by the Calliphorids, Bufolucilia silvarum and Bufolucilia elongata, in Wood Frogs, Rana sylvatica, From Southeastern Wisconsin" (2004). John Janovy Publications. 11.

https://digitalcommons.unl.edu/bioscijanovy/11
\end{abstract}

This Article is brought to you for free and open access by the Papers in the Biological Sciences at DigitalCommons@University of Nebraska - Lincoln. It has been accepted for inclusion in John Janovy Publications by an authorized administrator of DigitalCommons@University of Nebraska - Lincoln. 


\title{
Observations on Myiasis by the Calliphorids, Bufolucilia silvarum and Bufolucilia elongata, in Wood Frogs, Rana sylvatica, From Southeastern Wisconsin
}

\author{
Matthew G. Bolek and John Janovy Jr., School of Biological Sciences, University of Nebraska-Lincoln, Lincoln, Nebraska 68588. e-mail: \\ mbolek@unlserve.unl.edu
}

ABSTRACT: Larvae of certain species of blowflies (Calliphoridae) can cause myiasis in frogs and toads, but there are few reports from North American amphibians. Of these, most are from toads (bufonids). In this study, we observe primary myiasis in a population of juvenile wood frogs, Rana sylvatica, collected on 22-23 August 2003, from southeastern Wisconsin and compare our observations with previous studies on myiasis from toads. Two (5\%) of 39 frogs were infected by the blow fly Bufolucilia silvarum, with an intensity of 28 and 31, whereas 1 (2.5\%) of 39 frogs was infected by the blow fly Bufolucilia elongata with an intensity of 14 . We found that (1) B. silvarum lay eggs on healthy wood frogs, (2) eggs hatch, with first-instar maggots penetrating under the skin, (3) maggots develop to mature third instars within 13$16 \mathrm{hr}$ of egg hatching, (4) maggots kill the host within 7-47 hr of egg hatching, and (5) maggots consume the entire frog carcass reducing it to bones within $42-59 \mathrm{hr}$ of egg hatching. Our observations on the time of death and how quickly carcasses of wood frogs were consumed by these maggots compared with previous studies on toads suggest that finding infected juvenile wood frogs may be uncommon. Therefore, myiasis by these flies on wood frogs and other small terrestrial anurans may be a phenomenon that is much more common than is currently observed. This is the first report of $B$. silvarum and $B$. elongata causing myiasis in wood frogs.

Myiasis in amphibians is caused by larvae of dipterans from Sarcophagidae, Calliphoridae, and Chloropidae, some of which can cause substantial mortality in their amphibian hosts (Dasgupta, 1962; Crump and Pounds, 1985; Schell and Burgin, 2001; Bolek and Coggins, 2002). During 2003, the blowflies, Bufolucilia silvarum and Bufolucilia elongate, were found infesting juvenile wood frogs, Rana sylvatica, in southeastern Wisconsin. Members of this genus have been reported as obligate or facultative parasites of amphibians, particularly species of Bufo, but there are few reports of these flies causing myiasis in North American ranid frogs (see Bolek and Coggins, 2002). Our observations on the rapid consumption of wood frog carcasses by these maggots suggest that myiasis on small terrestrial anurans may be more common in North America than is currently observed.
In North America, 2 species of Bufolucilia have been reported to cause myiasis in 3 species of amphibians. Bufolucilia elongata caused myiasis in 1 boreal toad, Bufo boreas boreas, and 6 American toads from Colorado and Wisconsin, respectively, whereas $B$. silvarum was reported from 48 bullfrogs, Rana catesbeiana, in California, 1 American toad from Nova Scotia (Canada), and 1 American toad from Ontario, Canada (James and Maslin, 1947; Hall, 1948; Anderson and Bennett, 1963; Bleakney, 1963; Briggs, 1975). More recently, studies on the life history of $B$. silvarum from 9 American toads examined by Bolek and Coggins (2002) indicate that these flies deposit eggs on the back and flanks of the amphibian host. The larvae hatch and migrate under the skin where they form a single lesion in the paratoid glands, back, neck, and front or hind legs, where development takes place, and all infected toads die within 1 day to 2 wk of infection (Bolek and Coggins, 2002). No other information is available on these flies infecting North American amphibians. In their review on the life history of B. silvarum, Bolek and Coggins (2002) hypothesized that juvenile terrestrial anurans that are diurnal and overlap in their ecology with this fly species may be more prone to parasitism by $B$. silvarum than is currently known. In this study, we report observations on the life history of $B$. silvarum and $B$. elongata in juvenile wood frogs, $R$. sylvatica, from southeastern Wisconsin and compare these data with infections by these 2 species of flies in American toads examined by Briggs (1975) and Bolek and Coggins (2002) from Wisconsin. Our observations indicate that these flies may kill small frogs in the genus Rana and consume the carcass more rapidly than toads and therefore may be less commonly observed parasitizing these hosts in nature. These observations may account for the numerous reports of myiasis of Bufolucilia spp. and other calliphorids such as Phaenicia sericata and Lucilia illustris in toads and rarely in other species of North American frogs (Anderson and Bennett, 1963; Stewart and Foote, 1974; Bolek and Coggins, 2002).

Thirty-nine juvenile wood frogs were collected by hand in the woods during the day on 22-23 August 2003 at the University of WisconsinMilwaukee field station, Ozaukee County, Wisconsin $\left(43^{\circ} 23^{\prime} \mathrm{N}\right.$, $\left.88^{\circ} 2^{\prime} \mathrm{W}\right)$. All frogs were measured $(2.97 \pm 0.27 \mathrm{~cm})$ and examined for external lesions, eggs, or maggots. Frogs suspected of being infected 
were placed in individual $8.45-\mathrm{L}$ tanks lined with moist paper towels for observation. Dead frogs were placed in 70-ml plastic jars along with their maggots and observed for time of carcass consumption. All other frogs were killed and necropsied within $72 \mathrm{hr}$ of collection. Third-stage maggots from each frog were placed in individual $70-\mathrm{ml}$ plastic jars containing moist sand and allowed to pupate. Some were boiled in distilled water and fixed in $95 \%$ ethanol and cleared in $10 \% \mathrm{KOH}$. The cephalopharingial skeleton and posterior spiracles of some third instars were dissected and mounted in glycerin as temporary slides. Adult flies were fed granulated sugar and banana peels for at least $24 \mathrm{hr}$ before being killed by freezing and were pinned or preserved in $70 \%$ ethanol. Adult flies were identified to genus (Shewell, 1987) and to species by keys in Hall (1948) and Hall and Townsend (1977). Prevalence, intensity, and mean intensity are according to Bush et al. (1997). Student's $t$-test was used to compare differences in snout vent length (SVL), mean intensity of Bufolucilia spp. maggots, and time of survival (in hr) of American toads collected by Bolek and Coggins (2002) and wood frogs infected in this study. An approximate $t$-test was calculated when variances were heteroscedastic (Sokal and Rohlf, 1981). Adult and larval flies were deposited in the Harold W. Manter Laboratory collection (University of Nebraska State Museum, Lincoln, Nebraska; HWML $45414, B$. silvarum larvae; $45415, B$. silvarum adult flies; HWML 45416, B. elongata larvae; 45417, B. elongata adult flies).

Only 3 of $39(7.7 \%)$ juvenile wood frogs collected on 22-23 August 2003 were infected by green blow flies. Two (5\%) of the frogs were infected with $B$. silvarum with intensities of 28 and 31 , whereas 1 (2.5\%) frog was infected with $B$. elongata with an intensity of 14 .

The single frog infected with $B$. elongata was collected with a single lesion on the abdomen, with third-instar maggots being clearly visible; this frog died within $24 \mathrm{hr}$ of collection. The other 2 frogs were collected with deposited fly eggs. These were white and attached to the amphibians back (Figs. 1, 2). Neither individual appeared to show any discomfort and no wound or lesion was observed on the skin of these frogs. Eggs hatched on 1 frog collected on 23 August 2003 sometime between 11.5 and $19 \mathrm{hr}$ after collection during the night, with second instars being present in a single wound on 24 August 2003 (Fig. 3). Eggs hatched within 13.5-15.5 hr of collection on the second frog. Observations indicated that both frogs had single lesions on the right hip (Fig. 3), with third instars being visible on the 2 frogs within 13$16 \mathrm{hr}$ of egg hatching (Figs. 4, 5). These 2 frogs died within 7 and 47 $\mathrm{hr}$ of egg hatching. Maggots of both species of calliphorids continued to feed on the carcass (Fig. 6) reducing it to liquid slurry of tissue and bones (Fig. 7). Maggots consumed the entire frog carcass, reducing it to bones within $42-59 \mathrm{hr}$ of egg hatching (Fig. 8). Third-stage maggots of $B$. silvarum turned into pupa within 2 days after leaving the carcass remains and emerged as flies within 7-8 days at room temperature. Third-stage maggots of $B$. elongata turned into pupa within 3 days after leaving the carcass remains and emerged as flies within 7-8 days at room temperature.

Comparisons of SVL, mean intensities of Bufolucilia spp., and time of survival (in hr) of 9 American toads and 3 wood frogs infected with Bufolucilia spp. collected by Bolek and Coggins (2002) from Waukesha County, Wisconsin, during 1998 and this study are given in Table I. There were statistically significant differences in SVL, intensities, and time of survival among these hosts. Although these sample sizes are small, the 9 juvenile-infected toads were larger, had significantly lower intensities of maggots, and lived significantly longer in the laboratory. It is unclear why wood frogs had higher mean intensity of Bufolucilia spp. than American toads. Observations on egg hatching of $B$. silvarum in 2 toads by Bolek and Coggins (2002) indicate that toads vigorously rub their hind legs over their back as if they were trying to dislodge the eggs. We observed egg hatching on a single wood frog, which did not attempt to dislodge any eggs with its hind legs during hatching. It may be that American toads can reduce the number of calliphorid maggots by dislodging eggs during hatching. More importantly, our observations on the time of death and how quickly carcass of wood frogs were consumed by these maggots suggest that finding infected juvenile wood frogs may be uncommon. Bolek and Coggins (2002) reported that infected toads died within 1 day to $2 \mathrm{wk}$; the maggots never consumed the entire toad carcass before leaving to pupate. In addition, observations by Briggs (1975) on infections of $B$. elongata on American toads in Wisconsin indicated that numerous toads were observed alive and dead at his study site.

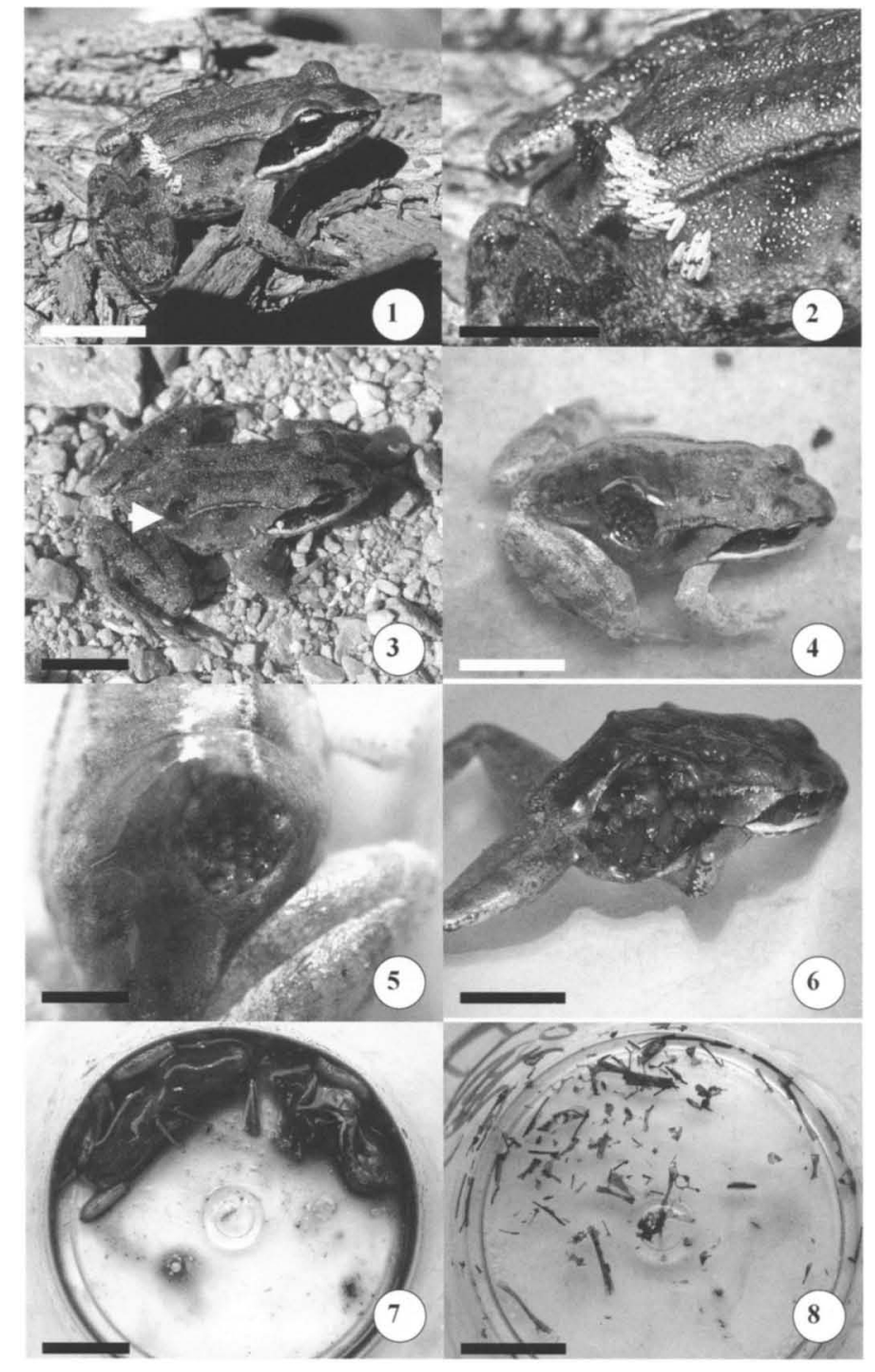

Figures 1-8. Photographs of successive stages and fate of a single young-of-the-year Rana sylvatica infected with Bufolucilia silvarum from southeastern Wisconsin. 1. Juvenile $R$. sylvatica with recently deposited $B$. silvarum eggs attached to the back. $B a r=1 \mathrm{~cm}$. 2. Higher magnification of eggs. Bar $=0.5 \mathrm{~cm}$. 3. Frog with a single lesion present on the right hip, with second instars being present. Bar $=1 \mathrm{~cm}$. 4. Frog with third instars present within $13-16 \mathrm{hr}$ of egg hatching. Bar $=1 \mathrm{~cm}$. 5. Higher magnification of third instars. Bar $=0.25 \mathrm{~cm} .6$. Third instars continued to feed on the carcass. Bar $=1 \mathrm{~cm}$. 7. Third instars quickly reduced the carcass into liquid slurry of tissue and bones. $\mathrm{Bar}=1 \mathrm{~cm}$. 8. Third instars reduced the carcass to bones and migrated out to pupate within $42-59 \mathrm{hr}$ of eggs hatching. Bar $=1 \mathrm{~cm}$.

These wood frogs were significantly smaller than toads examined by Bolek and Coggins (2002). Size probably plays a role in how quickly they are consumed by maggots of these flies. Adult wood frogs reach a maximum size of only $3-5 \mathrm{~cm}$, and most adults spend long inactive periods in the leaf litter or under logs during the summer (Vogt, 1981). The only common wood frogs found during the day in the summer are juveniles, and we suspect that this age group of frogs overlaps ecologically more commonly with Bufolucilia spp., which are diurnal (Hall, 1948; Vogt, 1981). These observations, along with the known time of consumption of carcasses of juvenile wood frogs in this study, indicate that wood frogs and other small anurans that overlap in their ecology with calliphorids may be more commonly parasitized by these flies but are rarely observed compared with bufonids.

We thank Melissa A. Ewert, Brigham and Women's Hospital, Boston, 
Bolek \& Janovy, Observations of Myiasis by Calliphorids in Wood Frogs from Southeastern Wisconsin Journal of Parasitology (2004) 90. Copyright 2004, American Society of Parasitologists. Used by permission.

TABLE I. Comparisons of SVL, mean intensity (MI), and time until death of juvenile American toads, Bufo americanus, and juvenile wood frogs, Rana sylvatica, infected with maggots of Bufolucilia species from southeastern Wisconsin.

\begin{tabular}{|c|c|c|c|c|}
\hline \multirow[b]{3}{*}{ Variable } & \multicolumn{2}{|c|}{ Host } & & \\
\hline & \multirow{2}{*}{$\begin{array}{l}\text { B. americanus } \\
\left(\mathrm{n}=9^{*}\right)\end{array}$} & \multirow{2}{*}{$\begin{array}{l}\text { R. sylvatica } \\
(\mathrm{n}=3)\end{array}$} & \multicolumn{2}{|c|}{ Statistics } \\
\hline & & & $t$ & $P$ \\
\hline $\mathrm{SVL}(\mathrm{cm} \pm 1 \mathrm{SD})$ & $4.1 \pm 0.23$ & $2.6 \pm 0.28$ & 8.78 & 0.0001 \\
\hline $\mathrm{MI}( \pm 1 \mathrm{SD})$ & $10.5 \pm 7.2$ & $24 \pm 9$ & 2.86 & 0.017 \\
\hline Time until death $(\mathrm{hr} \pm 1 \mathrm{SD})$ & $114.33 \pm 100.84$ & $26 \pm 20$ & 2.48 & 0.035 \\
\hline
\end{tabular}

* Data from Bolek and Coggins (2002).

Massachusetts, for help in collecting frogs and James R. Coggins and Gretchen A. Meyer, Department of Biological Sciences, University of Wisconsin-Milwaukee, for allowing us access to collect frogs at the UWM field station. We thank Agustin Jimenez Ruiz, Harold W. Manter Laboratory, University of Nebraska-Lincoln, for reviewing the manuscript and 2 anonymous reviewers for improvements on the manuscript. This work was supported by a grant to M.G.B. from the School of Biological Sciences Special Funds, University of Nebraska-Lincoln.

\section{LITERATURE CITED}

Anderson, R. C., AND G. F. Bennett. 1963. Ophthalmic myiasis in amphibians in Algonquin Park, Ontario, Canada. Canadian Journal of Zoology 41: 1169-1170.

Bleakney, J. S. 1963. First North American record of Bufolucilia silvarum (Meigen) (Diptera: Calliphoridae) parasitizing Bufo terrestris americanus Holbrook. The Canadian Entomologist 95: 107.

BoleK, M. G., AND J. R. CoGgINs. 2002. Observations on myiasis by the calliphorid, Bufolucilia silvarum, in the eastern American toad (Bufo americanus americanus) from southeastern Wisconsin. Journal of Wildlife Diseases 38: 598-603.

BRIGGS, J. L. 1975. A case of Bufolucilia elongata shannon 1924 (Diptera: Calliphoridae) myiasis in the American Toad, Bufo americanus Holbrook 1836. Journal of Parasitology 61: 412.

Bush, A. O., K. D. Lafferty, J. M. Lotz, AND A. W. Shostak. 1997. Parasitology meets ecology on its own terms: Margolis et al. revisited. Journal of Parasitology 83: 575-583.
Crump, M. L., AND J. A. Pounds. 1985. Lethal parasitism of an Aposematic anuran (Atelopus varius) by Notochaeta bufonivora (Diptera: Sarcophagidae). Journal of Parasitology 71: 588-591.

DASGUPTA, B. 1962. On the myiasis of the Indian toad Bufo melanostictus. Parasitology 52: 63-66.

Hall, D. G. 1948. The blowflies of North America. The Thomas Say Foundation, Baltimore, Maryland, $477 \mathrm{p}$.

Hall, R. D., AND L. H. TownsEnd. 1977. The insects of Virginia No. 11. Research division bulletin 123. Virginia Polytechnic Institute and State University, Blacksburg, Virginia, $48 \mathrm{p}$.

JAMES, T. M., AND T. P. MASLIN. 1947. Notes on myiasis of the toad, Bufo boreas boreas Baird and Girard. Journal of the Washington Academy of Sciences 37: 366-368.

SCHEll, C. B., AND S. BuRgin. 2001. Batrachomyia strigapes (Diptera) parasitism of Uperoleia laevigata (Anura). Journal of Parasitology 87: 1215-1216.

SHEwELL, G. E. 1987. Calliphoridae. In Manual of Nearctic Diptera 2 Monograph 28, J. F. McAlpine (ed.). Research Branch Agriculture Canada, Ottowa, Canada, p. 1133-1145.

SOKal, R. R., AND J. F. RoHLF. 1981. Biometry, 2nd ed. W. H. Freeman and Company, New York, 859 p.

Stewart, S., AND R. H. Foote. 1974. An unusual infestation by Phaenicia sericata (Mg.) (Diptera: Calliphoridae). Proceedings of the Entomological Society of Washington 76: 466.

VoGT, R. C. 1981. Natural history of amphibians and reptiles of Wisconsin. The Milwaukee Public Museum and Friends of the Museum Inc., Milwaukee, Wisconsin, 205 p. 